\title{
LIFE HISTORY AND ECOLOGY OF DIPLOPERLA ROBUSTA STARK AND GAUFIN (PLECOPTERA: PERLODIDAE)
}

\author{
By Diana L. Ashley, ' Donald C. Tarter ${ }^{1}$ \\ AND WILliam D. WATKINS ${ }^{2}$
}

The purpose of this study was to describe the life history and ecology of the perlodid stonefly Diploperla robusta Stark and Gaufin in a small, woodland stream in Cabell County, West Virginia. No papers have been published on the life history and ecology of D. robusta. Ashley (1977) reported that the naiads of $D$. robusta have a $\mathrm{TL}_{\mathrm{m}}{ }^{96} \mathrm{pH}$ value of 4.6. Several investigators, including Smith (1913), Needham and Claassen (1925), Claassen (1931), Frison (1935, 1942), Ricker (1949), Minshall and Minshall (1966), Tarter and Krumholz (1971), Harper (1973), and Vaught and Stewart (1974), have reported studies on the ecology of North American stoneflies.

\section{TAXONOMY AND DISTRIBUTION}

Diploperla was originally listed as a subgenus of Perla by Needham and Claassen (1925). Ricker (1952) considered it a monotypic subgenus of Isogenus. Illies (1966) gave it generic status and listed the only species as Diploperla duplicata (Banks). In 1974, Stark and Gaufin described D. robusta to replace what had been named $D$. duplicata. According to Stark and Gaufin (1974), D. duplicata and D. robusta are two distinct species.

The known range of $D$. robusta is in the eastern portion of the United States, including Kentucky, Indiana, Ohio (Stark and Gaufin, 1974), and West Virginia. According to Hissom and Tarter (1976), D. robusta is recorded from 20 counties in West Virginia.

\section{MATERIALS AND METHODS}

The study area is an unnamed tributary of Fourpole Creek, Cabell County, West Virginia. The county is located at $82^{\circ} 24^{\prime} 43^{\prime \prime} \mathrm{W}$

'Dept. of Biol. Sci., Mashall Univ., Huntington, W. Va. 25701

${ }^{2}$ Ashland Oil Inc., Res. and Dev. Dept., Catlettsburg. Ky.

Manuscript received by the editor May 3, 1977 
longitude and $38^{\circ} 22^{\prime} 52^{\prime \prime} \mathrm{N}$ latitude. It varies in elevation from $150.6 \mathrm{~m}$ at the mouth of Fourpole Creek to $355.1 \mathrm{~m}$ at a knob located in Salt Rock (Krebs and Teets, 1913). The tributary is $3.2 \mathrm{~km}$ long and $1.5 \mathrm{~m}$ wide. The substrate of the stream bed is gravel and sand. The riparian woodland is primarily composed of box elder, Acer negundo L.; red maple, A. rubrum L.; sugar maple, A. saccharum Marsh.; white oak, Quercus alba L.; redbud, Cercis canadensis L.; and hop hornbeam. Ostrya virginiana (Mull.) K. Koch.

Intensive and systematic field collections were made monthly between 26 April 1975 and 30 September 1976. The collections of naiads were done in ten minute sampling periods. A long handled dredge with a fine mesh net (60 threads per inch) was raked along the substrate. By kicking the substrate, the naiads were loosened from their habitat and drifted into the net, and subsequently were preserved in 10 percent formalin.

Water temperature was measured with a mercury thermometer placed near the collecting site. The following water chemistry parameters were measured with a Hach chemical kit. Model A1-36-WR: hydrogen ion concentration $(\mathrm{pH})$, dissolved oxygen, total hardness, carbon dioxide, and alkalinity (carbonate and bicarbonate).

In order to determine size classes, length-frequency histograms were arranged in $1 \mathrm{~mm}$ groups for 320 D. robusta naiads. The naiads were measured by a dial vernier caliper (nearest 0.1 $\mathrm{mm}$ ). The monthly index of growth was determined by head width which was measured for 320 D. robusta naiads by an ocular micrometer (nearest $0.1 \mathrm{~mm}$ ) in a Bausch and Lomb dissecting microscope.

Naiadal food habits were determined by foregut analysis. For each month ten naiads were chosen at random. The foregut was removed by cutting off the head and making a ventral incision to the abdomen. The foregut was cut from the anterior end of the hindgut and placed on a slide with a drop of water. It was then carefully slit open and its contents emptied into the water. A Bausch and Lomb dissecting microscope was used to identify the contents. The percentage frequency of occurrence (\%FO) was computed for each item and the average number of specimens with foreguts containing each item $(\overline{\mathrm{x}})$ was determined.

To study the emergence pattern of $D$. robusta, the study area 
was searched for adults on the wing or exuviae in the months when no naiads were found (May through July). The rocks and vegetation were checked for the shed skins of adults.

Fecundity in the adult stonefly was determined by direct counts of the ovarian eggs using a binocular dissecting microscope (Bausch and Lomb). Both ovaries were excised from 15 females (only eight contained eggs) and 241 eggs were counted. The diameters of 20 percent of the eggs from eight females were measured with an ocular micrometer (nearest $0.1 \mathrm{~mm}$ ) under a Bausch and Lomb dissecting microscope.

The chi-square test was applied to 23 laboratory reared adults to determine any significant departure from the 1:1 ratio at the 0.05 confidence level.

\section{RESULTS AND DISCUSSION}

Stream Environment.-The average annual temperature in the tributary for the study period was $13.9 \mathrm{C}$. The monthly extremes were 5 and $22.7 \mathrm{C}$ in November and August, respectively. The hydrogen ion concentration $(\mathrm{pH})$ ranged from 7.5 to 8 , with an average of 7.8. Dissolved oxygen concentration ranged from 4 to $15 \mathrm{mg} / 1$ in August and January, respectively, with a mean of $8.5 \mathrm{mg} / \mathrm{l}$. Carbon dioxide values ranged from $5 \mathrm{mg} / 1$ in April, May, June, January and February to $25 \mathrm{mg} / \mathrm{l}$ in October. The mean was $18.7 \mathrm{mg} / \mathrm{l}$. Total hardness ranged from 88.5 to 205.2 $\mathrm{mg} / \mathrm{l}$ in April and November, respectively, with a mean of 135.6 $\mathrm{mg} / \mathrm{l}$. Carbonate alkalinity values ranged from 34.2 to $136.8 \mathrm{mg} / \mathrm{l}$ in April and October, respectively: the mean value was $72.7 \mathrm{mg} / \mathrm{l}$. Naiadal Development.-Length-frequency histograms indicated that one size class was present in the naiadal population of D. robusta (Figure 1). The earliest naiad was collected 30 August 1975 and measured $2.8 \mathrm{~mm}$ in body length. The largest naiad was found 26 April 1976 and measured $16.9 \mathrm{~mm}$ in body length. No naiads were found in the stream from May through July.

Frison (1935) stated that Isoperla duplicata $(=D$. robusta $)$ is univoltine in Turkey Run State Park (Newby Gulch), Indiana. Minshall and Minshall (1966) did a study on two other perlodid stoneflies, Isoperla clio (Newman) and Isogenus decisus Walker and found both to be univoltine. 


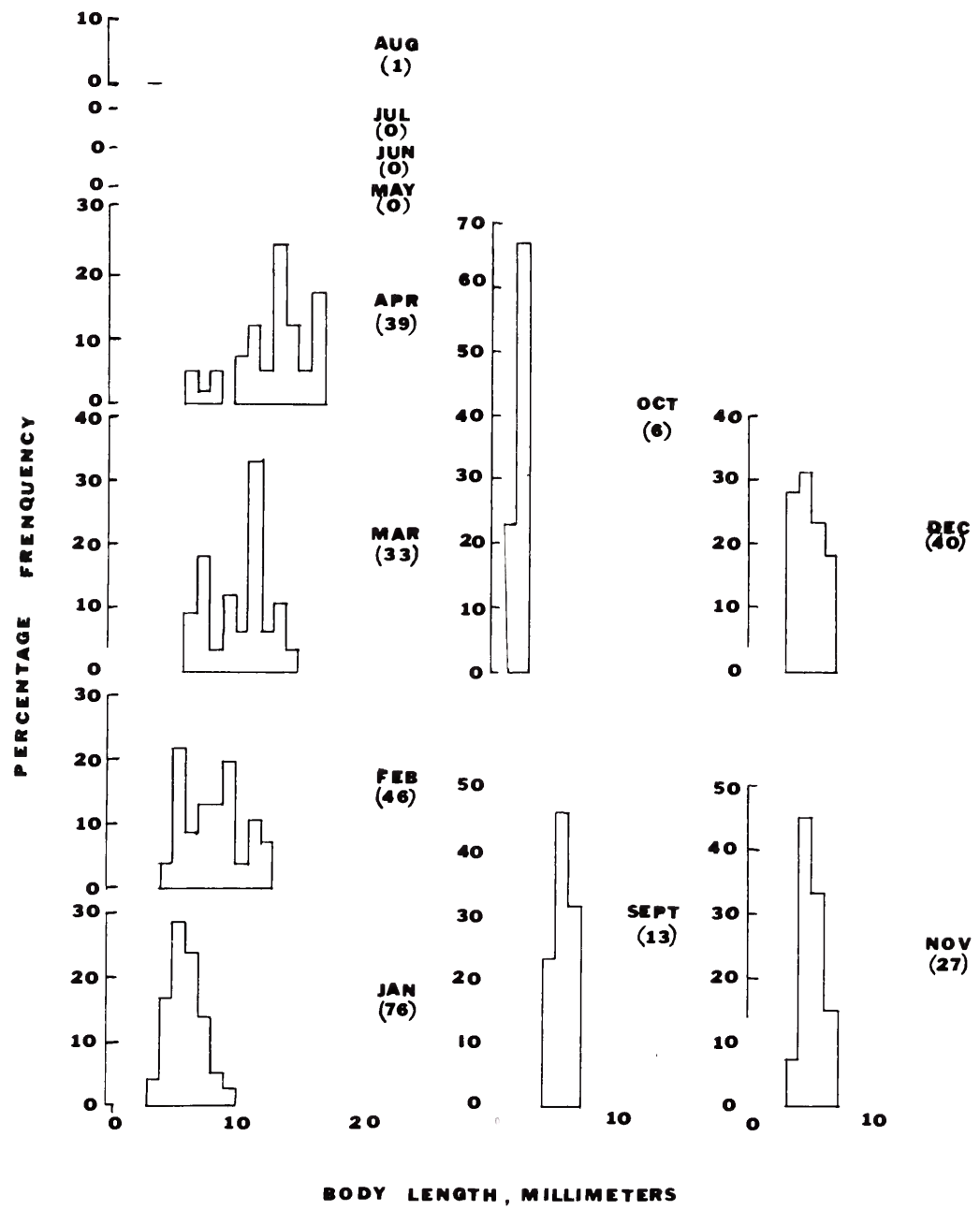

Figure 1. Length-frequencies at monthly intervals for Diploperla robusta naiads from a small, woodland stream, Cabell County, West Virginia. The number of naiads collected each month is given in parentheses. 
Head widths of the naiads were used to show the monthly variation in growth (Figure 2). Naiads collected in March and April had a mean head width of 1.9 and $2.4 \mathrm{~mm}$ (maximum width), respectively. This represented the greatest growth rate, 49 percent, throughout the year. No naiads were found from May to July, and the appearance of one naiad in August, $0.62 \mathrm{~mm}$ head width, corroborates the theory of a new size class beginning.

From November through April, the temperature steadily increased from 5 to $15 \mathrm{C}$, corresponding to the increase in mean head widths and greatest growth rate (March to April). When the new size class appeared in August, the temperature was $22.7 \mathrm{C}$ and dropped steadily until November when the previous pattern began again.

Naiadal Food Habits.-Of the 76 foreguts examined, $30(40 \%)$ contained food and $46(60 \%)$ were empty. Foregut analyses of the naiads of $D$. robusta indicated that dipteran larvae, primarily chironomids, ranked first in percentage frequency of occurrence in all seasons. From December through February, chironomids comprised the total foregut contents. There was an average of 5.6, 4.9, and 2.8 larvae per foregut in December, January, and February, respectively. In March and April, the naiads fed on chironomids and mayflies (Baetidae). The chironomids averaged 5.6 and 10.8 per foregut in March and April, respectively, and the mayflies averaged 1.5 and 1.0 per foregut in March and April, respectively. No naiads were collected from May to July. When the size class was beginning in August, the single stonefly found contained no food. Likewise, from September to November, no foregut contents were found in the naiads. Many diatoms were found in the foreguts of D. robusta naiads. The predominant species were Navicula spp. and Surirella sp., and in smaller numbers, Meridion sp., Rhoicosphenia sp., and Fragillaria sp.

Frison (1935) stated that Isoperla duplicata $(=$ D. robusta) was carnivorous but did not mention its diet. Minshall and Minshall (1966) noted that two other perlodid stoneflies were carnivorous. They reported that Isoperla clio and Isogenus decisus fed on larval chironomids and mayflies (Baetidae).

Adult Stage.-When the naiads of D. robusta are ready to emerge as adults, they crawl from the water to the surrounding vegetation or rocks. The emergence data were calculated by counting exuviae found on the concrete base of a bridge. Few adults were 


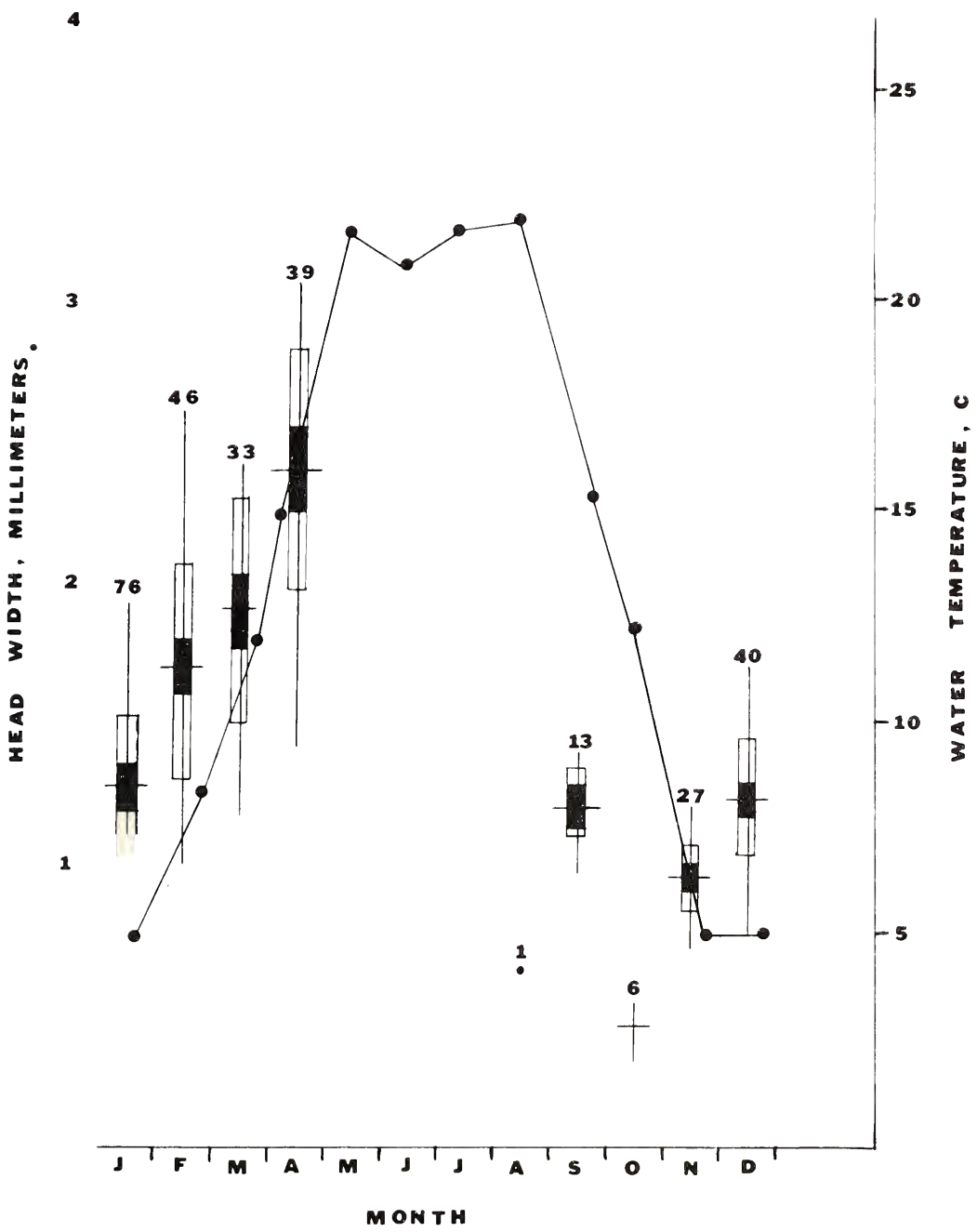

Figure 2. Monthly variation of the head widths in Diploperla robusta naiads from a small, woodland stream, Cabell County, West Virginia. Vertical lines $=$ ranges, horizontal lines $=$ means, dark rectangles $=$ two times the standard error of the mean, larger open rectanges $=$ one standard deviation, numbers $=$ sample sizes, and solid lines = temperature $(\mathrm{C})$. 
observed. On May 11, at a temperature of $20 \mathrm{C}$, the first exuviae (19) were found at the water line and up to four feet on the wall of the bridge. One adult female was found parasitized in a spider's nest. The peak of emergence was on May 12 when 31 exuviae and three females were collected. From May 13 through 19, 51 exuviae were collected from the wall of the bridge.

Minshall and Minshall (1966) found the adults of Isoperla clio and Isogenus decisus emerged between 4:30 and 6:30 PM. Minshall and Minshall (1966) stated they found Isoperla clio exuviae several meters away from the stream, with the first adults collected in April, then a few in June, with a peak in April. According to Harper (1973), I. clio adults emerged on May 17 and lasted 20 days. He also reported on other setipalpian Plecoptera and the emergence patterns are all similar.

The direct count of ovarian eggs of fifteen females (only eight contained eggs) resulted in a range of 4 to 60 eggs per female; the mean was 30 . Seven of the females examined had ovaries containing undeveloped eggs or none at all. The eggs of D. robusta are spindle shaped and light, golden-brown color.

Twenty percent of the eggs from eight females had a range of 0.28 to $0.43 \mathrm{~mm}(\overline{\mathrm{x}}=0.39)$ in length and 0.21 to $0.32 \mathrm{~mm}(\overline{\mathrm{x}}=$ 0.27 ) in diameter.

The months of May through July for two summers revealed no naiads in the stream. At this time, the stream was dried up and possibly the eggs of $D$. robusta were diapausing for 12-14 weeks. The rains of August caused the stream to be normal again and at this time the naiads, very small in size, reappeared.

Under laboratory conditions, Miller (1939) reported that the eggs of Pteronarcys ( $=$ Allonarcys) proteus Newman diapaused from 305 to 325 days. Diapause was apparently not obligatory since hatching was forced by high temperature. Harden and Mickel (1952) reported that the eggs of Isoperla bilineata (Say) oviposited in June and maintained in the laboratory did not hatch until October. The eggs of I. clio apparently hatch in August and September (Minshall and Minshall, 1966).

The chi-square test indicated a significant departure from the 1:1 ratio at the 0.05 confidence level. The sex ratio was based on a laboratory reared sample of 8 males and 15 females, a ratio of about 53 males to 100 females. 
To determine longevity of $D$. robusta, several naiads with dark wing pads were placed in rearing cages. The average time any single adult lived was five to six days.

A male and female adult were placed in a cage together to observe mating behavior. They both died before mating occurred. Reproductive behavior was reported in two other perlodid stoneflies by Minshall and Minshall (1966). Isoperla clio and Isogenus decisus females apparently deposit their eggs directly into the water in the form of packets by dipping the tip of the abdomen while in flight.

Ashley, D. L.

\section{REFERENCES}

1977. Low $\mathrm{pH}$ tolerance of the naiads of the stonefly Diploperla robusta Stark and Gaufin, under controlled conditions. Proc. W. Va. Acad. Sci. 49(1): 23.

Claassen, P. W.

1931. Plecoptera nymphs of America (north of Mexico). Thomas Say Found. Ent. Soc. Amer. 3: 1-199.

Frison, T. H.

1935. The stoneflies of Illinois. Bull. Ill. Nat. Hist. Surv. 20(4): 275-471.

1942. Studies of North American Plecoptera with special references to the fauna of Illinois. Bull. Ill. Nat. Hist. Surv. 22(2): 235-355.

Harden, P., and C. Mickel.

1952. The stoneflies of Minnesota (Plecoptera). Univ. Minn. Agric. Exp. Sta. Tech. Bull. 201: 84 pp.

HARPER, P. P.

1973. Emergence, reproduction, and growth of setipalpian Plecoptera in southern Ontario. Oikos 24: 94-107.

Hissom, F. K., AND D. C. TARTER.

1976. Taxonomy and distribution of nymphal Perlodidae of West Virginia (Insecta: Plecoptera). J. Ga. Ent. Soc. 11(4): 317-323.

ILLIES, $\mathbf{J}$.

1966. Katalog der rezenten Plecoptera. Das Tierreich, 82. Walter de Gruyter and Co., Berlin. 632 pp.

Krebs, C. E. , and D. D. Teets, JR.

1913. West Virginia Geological Survey. County Reports (Cabell, Wayne and Lincoln Co.), p. 32.

Miller, A.

1939. The egg and early development of the stonefly Pteronarcys proteus Newman. J. Morph. 64(3): 555-604.

Minshall, G. W., ANd J. N. Minshall.

1966. Notes on the life history and ecology of Isoperla clio (Newman) and Isogenus decisus Walker (Plecoptera: Perlodidae). Amer. Midl. Nat. 76(2): 340-350. 
Needham, J. G., and P. W. Claassen.

1925. A monograph of the Plecoptera of America north of Mexico. Thomas Say Found. Ent. Soc. Amer. 2: 1-397.

RICKER, W. E.

1949. The North American species of Paragnetina (Plecoptera: Perlidae). Ann. Ent. Soc. Amer. 42(3): 279-288.

1952. Systematic studies in Plecoptera. Ind. Univ. Pub. Sci. Ser. No. $18,200 \mathrm{pp}$.

SMITH, L. W.

1913. The biology of Perla immarginata Say. Ann. Ent. Soc. Amer. 6(2): $203-211$.

Stark, B. P. and A. R. Gaufin.

1974. The genus Diploperla (Plecoptera: Perlodidae). J. Kans. Ent. Soc. 47(4): 433-436.

Tarter, D. C., and L. A. Krumholz.

1971. Life history and ecology of Paragnetina media (Walker), in Doe Run, Meade County, Kentucky. Amer. Midl. Nat. 86(1): 169-180.

Vaught, G. L., and K. W. Stewart.

1974. The life history and ecology of the stonefly Neoperla clymene (Newman) (Plecoptera: Perlidae). Ann. Ent. Soc. Amer. 67(2): 167-178. 


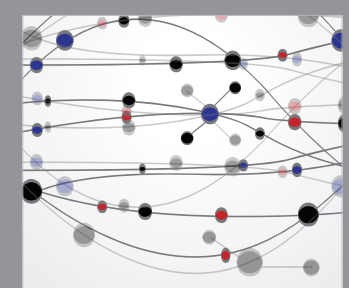

The Scientific World Journal
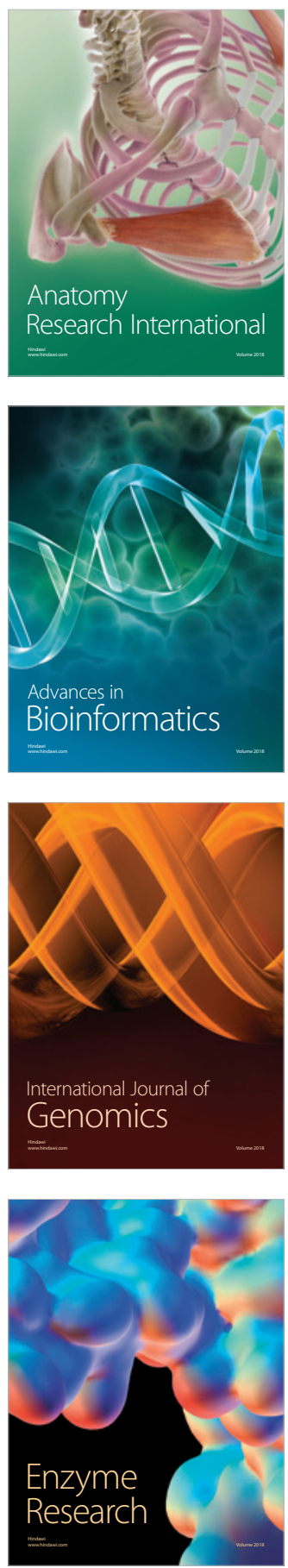
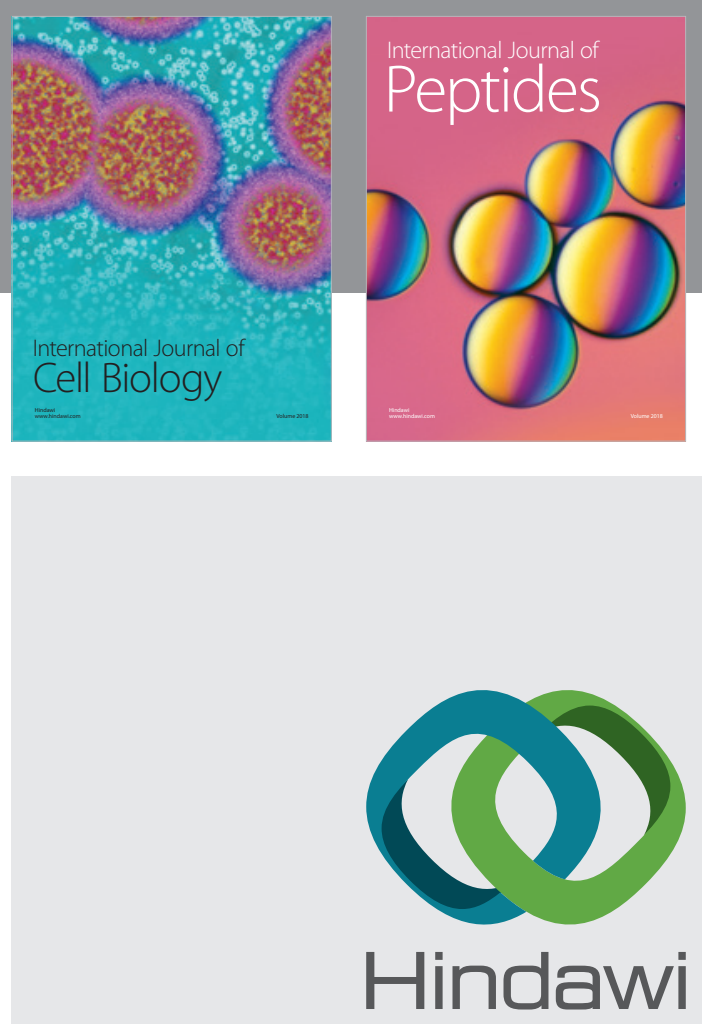

Submit your manuscripts at

www.hindawi.com
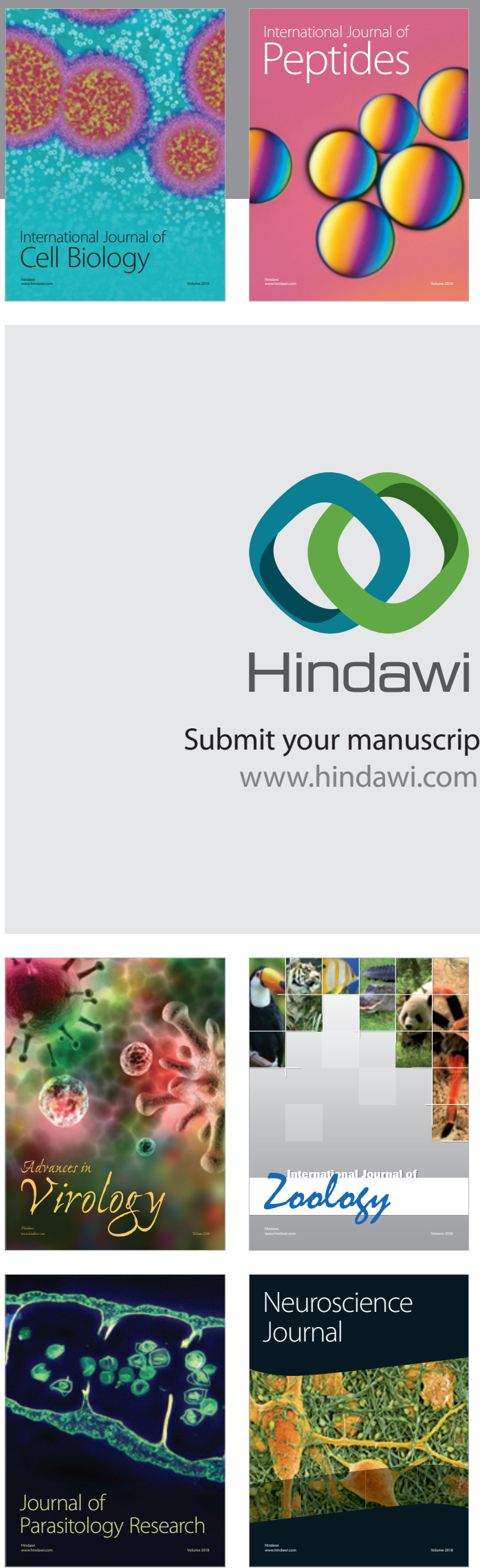
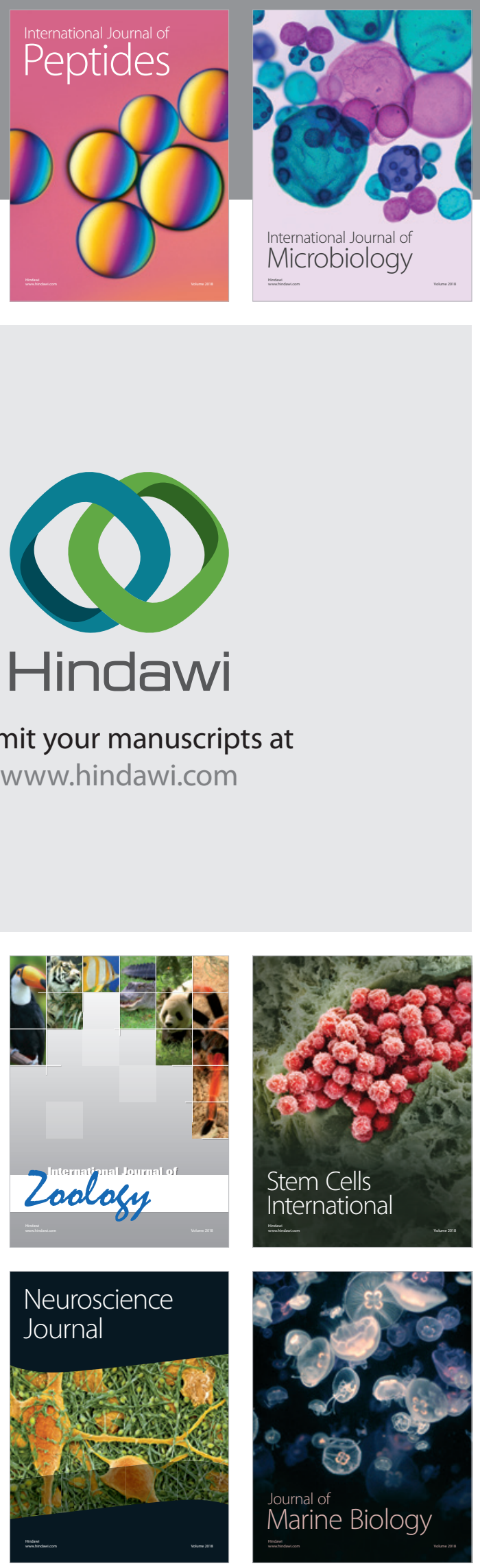
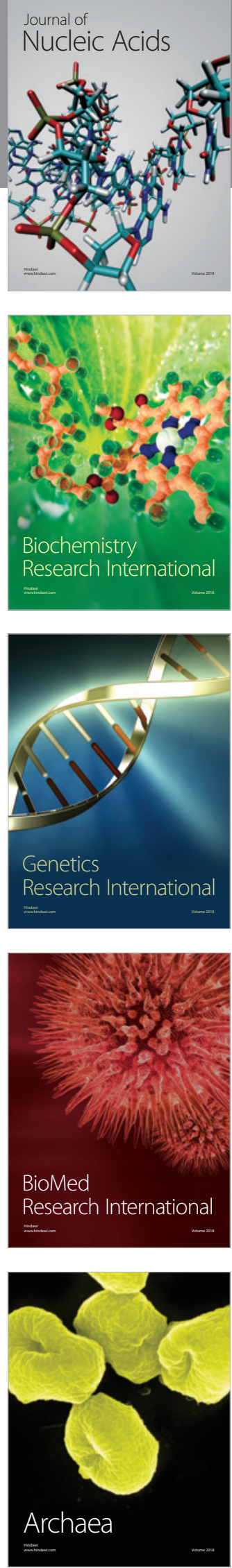